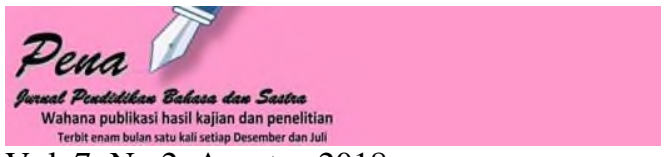

Vol. 7, No.2, Agustus 2018,

P-ISSN: 2089-3973, E-ISSN: 2615-7705

DOI: https://doi.org/10.22437/pena.v7i2.5316

\title{
Kritik Sosial Stand Up Comedy Indonesia dalam Tinjauan Prakmatik
}

\author{
Apri Damai Sagita Krissandi, Kelik Agung Cahya Setiawan \\ Universitas Sanata Dharma Yogyakarta \\ apridamai@gmail.com
}

\begin{abstract}
Abstrak
Tujuan penelitian ini untuk mendeskripsikan wujud kritik sosial yang terdapat dalam stand up comedy studi kasus comic Abdurrahum Arsyad dan mendeskripsikan penyimpangan prinsip kerja sama yang terdapat dalam stand up comedy studi kasus comic Abdurrahum Arsyad. Metode analisis menggunakan perspektif pragmatik. Berdasakan hasil analisis mengenai wujud penyimpangan prinsip kerja sama dan kritik sosial yang terdapat dalam stand up comedy yang disampaikan oleh Abdurrahum Arsyad maka dapat disimpulkan bahwa: (1) wujud penyimpangan prinsip kerja sama yang terdapat dalam stand up comedy Indonesia season 4 oleh comic Abdurrahum Arsyad terdiri dari penyimpangan maksim kuantitas, maksim kualitas, maksim relevansi dan maksim pelaksanaan. (2) Stand up comedy merupakan salah satu jenis humor yang berkembang di masyarakat yang diungkapkan dengan melanggar maksim kuantitas, kualitas, relevansi, dan pelaksanaan dapat digunakan sebagai sarana untuk menyampaikan kritik sosial karena dapat diungkapkan dengan bahasa yang harmonis dan mempunyai kesan santai serta menggelitik.
\end{abstract}

Kata kunci : kritik sosial, stand up comedy, pragmatik

\begin{abstract}
This study aimed to describe the form of social criticism contained in the stand-up comedy comic case study Abdurrahum Arsyad and describes the deviation of the principle of cooperation contained in stand up comedy comic case study Abdurrahum Arsyad. The analytical method used a pragmatic perspective. Based on the analysis of the existence of deviations from the principles of cooperation and social criticism contained in the stand up comedy presented by Abdurrahum Arsyad, it can be concluded that: (1) a deviation of the cooperation principle contained in the stand up comedy Indonesia season 4 by comic Abdurrahum Arsyad from maximal deviations of quantity, maxim of quality, maxim of relevance and maxim of implementation. (2) Stand up comedy is one type of humor that develops in a society expressed by violating the maxim of quantity, quality, relevance, and execution can be used as a means of conveying social criticism because it can be expressed in harmonious language and has a relaxed and intriguing impression.
\end{abstract}

Keywords : social criticism, stand up comedy, pragmatik

\section{PENDAHULUAN}

Bahasa merupakan suatu hal yang penting dalam kehidupan manusia. Secara umum bahasa digunakan sebagai sarana manusia untuk menyampaikan pesan atau maksud pembicara pada pendengar. Bahasa yang digunakan tersebut akan mengarah kepada terbentuknya komunikasi sosial. Secara sederhana komunikasi dapat diartikan sebagai suatu kegiatan pertukaran informasi antara pemberi informasi dan penerima informasi 


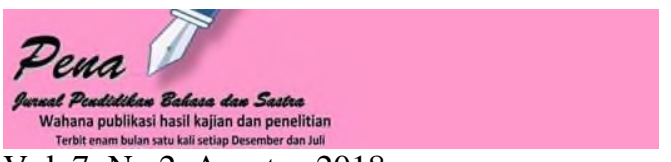

Vol. 7, No.2, Agustus 2018,

P-ISSN: 2089-3973, E-ISSN: 2615-7705

DOI: https://doi.org/10.22437/pena.v7i2.5316

(Andiopenta, 2011:77). Komunikasi yang terjalin dari individu kepada masyarakat disampaikan mempunyai maksud tertentu. Salah satu bentuk komunikasi yang mempunyai maksud tertentu adalah humor.

Humor merupakan salah satu sarana komunikasi yang berbentuk rangsangan yang cenderung secara spontan menimbulkan senyum dan tawa para penikmantya (Wijana, 2004: 37). Humor juga mempunyai peran yang cukup penting dalam kehidupan manusia. Humor bukan hanya sekedar sebagai hiburan untuk melepaskan ketegangan dan beban psikologis dari penikmatnya. Namun juga sebagai sarana kritik sosial terhadap penyimpangan yang terjadi dalam masyarakat. Melalui humor, kritik sosial dapat diungkapkan dengan bahasa yang harmonis dan mempunyai kesan santai serta menggelitik bagi penikmatnya. Perlu kecerdasan baik dari penutur ataupuan lawan tutur untuk menciptakan humor. Penutur perlu menempatkan humor pada saat yang tepat, sebab jika humor dilepaskan pada saat yang tidak tepat maka humor tersebut bukan hanya tidak lucu namun dapat juga mengakibatkan lawan tutur merasa tersakiti. Lawan tutur juga harus bersikap arif dalam menanggapi sebuah humor, sebab setajam apapun kritikan dalam sebuah humor, tetaplah sebuah humor.

Humor mempunyai manfaat jika terdapat sarana pengungkap humor, pengungkap humor ini tidak lain adalah bahasa. Bahasa yang mempunyai fungsi sebagai alat komunikasi sosial dapat mempermudah proses komunikasi dalam masyarakat. Komunikasi sendiri diartikan sebagai suatu proses penyampaian informasi dari penutut kepada mitra tutur mitra tutur agar mengerti apa yang dimaksud oleh penutur (Hendri, 2017: 100). Salah satu kajian bahasa yang menjelaskan mengenai tindak tutur dalam rangkan berkomunikasi adalah pragmatik. Abdul Chaer (2010:23) menjelaskan pragmatik merupakan ilmu yang mengkaji bagaimana satuansatuan bahasa digunakan dalam pertuturan dalam rangka melaksanakan komunikasi. Levison (1983:15) berpendapat bahwa penggunaan bahasa sebagai alat komunikasi dalam pragmatik mempunyai kaidah-kaidah yang harus dipatuhi oleh penutur dan mitra tutur. Prinsip kerja sama merupakan salah satu pedoman dalam berkomunikasi sehingga tindak tutur yang disampaikan dapat diterima dengan efisien, rasional dan maksimal. Penyimpangan yang dilakukan saat melakukan tuturan akan bedampak pada tidak efektifnya komunikasi.

Wijana (2004:5-6) menyatakan jika penyimpangan terhadap prinsip kerja sama dalam komunikasi maka akan berakibat komunikasi tidak lancar. Namun penyimpangan yang 


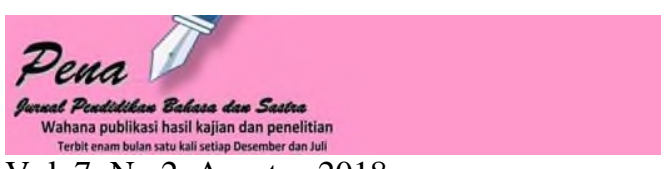

Vol. 7, No.2, Agustus 2018,

P-ISSN: 2089-3973, E-ISSN: 2615-7705

DOI: https://doi.org/10.22437/pena.v7i2.5316

dilakukan justru akan dapat digunakan sebagai sarana menciptakan humor dan munculnya humor dapat dijelaskan secara linguis. Humor memiliki berbagai jenis yang berkembang di masyarakat. Stand up comedy merupakan salah satu jenis humor yang berkembang di masyarakat. Di Indonesia stand up comedy merupakan salah satu jenis humor yang cukup populer. Stand up comedy mulai muncul dan berkembang di Eropa dan Amerika Serikat sekitar tahun 1970-1980. Pada tahun 1979 di Inggris terbentuk sebuah kelompok stand up comedy dengan gaya Amerika yang didirikan oleh Peter Rosengard. Kelompok ini menjadi pelopor terkait dengan bermunculan kelompok-kelompok stand up comedy diberbagai penjuru dunia. Seiring dengan berjalannya waktu, stand up comedy telah menyebar di seluruh dunia salah satunya di Indonesia. Stand up comedy muncul di Indonesia sekitar tahun 1992 yang dipopulerkan oleh dua tokoh yaitu Roman Papana dan Harry de Frates (Papana, 2012:9).

Saputra, dkk (2015:87) menyatakan bahwa Stand up comedy merupakan monolog yng diungkapkan dengan maksud untuk mengungkapkan sesuatu yang tersembunyi atau digunakan untuk menyindir. Orang yang melakukan komedian dalam stand up disebut dengan Comic. Comic sebagai pelaku utama dalam memberikan gambaran mengenai humor, lelucon, sindirian, bahkan kritikan yang dikemas dengan berbagai tuturan dan gerakan. Tujuan utama dari comic adalah untuk menghibur penikmat stand up dengan menampilkan lawakan yang cerdas. Materi lawakan dikemas dengan tema tertentu. Salah satu materi yang diangkat adalah kritik sosial. Salah satu comic yang terkenal dan sering mengangkat kritik sosial dalam stand up comedy di Indonesia adalah Abdurrahim Arsyad atau biasa dikenal dengan Abdur.

Berdasarkan latar belakang yang sudah dijelaskan, maka masalah dalam artikel ini adalah bagaimana wujud penyimpangan prinsip kerja sama yang terdapat dalam stand up comedy Indonesia season 4 show9-ronde 1 oleh comic Abdurrahum Arsyad, dan bagaimana kritik sosial yang terdapat dalam stand up comedy Indonesia season 4 show9-ronde 1 oleh comic Abdurrahum Arsyad dalam perspektif pragmatik. 


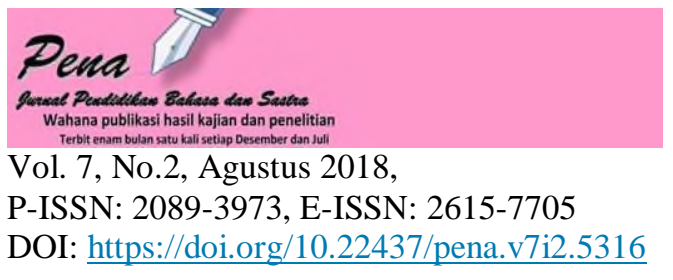

\section{KAJIAN TEORI}

\section{Pengertian Humor}

Humor secara umum dapat diartikan sebagai rangsangan mental yang menyebabkan orang tertawa (Firmansyah dan Rokhmawan, 2016: 43). Senada dengan itu, Setiawan (1990: 34-35) menyatakan bahwa humor adalah rasa atau gejala yang merangsang penutur dan lawan tutur untuk tertawa secara mental, humor bisa berupa rasa kesadaran dalam diri dan bisa berupa gejala atau hasil cipta dari dalam maupun luar diri. Dari pengertian yang sudah dijelaskan, maka humor merupakan rangsangan secara verbal atau visual yang merangsang penutur untuk memancing respon yang dinyatakan dalam senyum ataupun tawa.

Menurut Wijana (2003:3) menyatakan bahwa dalam humor harus dapat menjadi pelipur lara melalui reaksi emosional, contohnya: tertawa dapat mengendurkan ketegangan batin akibat dari persoalan sosial yang dihadapi individu. Dengan demikian, humor tidak hanya sebagai hiburan saja, melainkan dapat pula menciptakan kondisi kejiwaan seseorang menjadi lebih baik dan tetap terjaga. (Pradopo, 1987:5) membagi tiga pengertian humor dalam teori superioritas, degradasi, frustasi. Superioritas memandang humor adalah aktivitas menertawakan sesuatu yang dianggap lebih rendah, lebih jelek, dan sebagainya sedangkan degradasi menyatakan humor terjadi karena ada penyimpangan antara konsep dengan objeknya, peloncatan tiba-tiba dari satu konteks ke konteks lain dan penggambungan dua peristiwa yang sesungguhnya saling terpisah. Frustasi memandang humor terjadi karena adanya pembebasan dari ketegangan psikis. Menurut Barger (2012:17) menyatakan bahwa ada empat beberapa teknik untuk menciptakan humor yaitu Language. The humor is verbal, Logic. The humor is ideational. , Identity. The humor is existential, Action. The humor is physical or nonverbal. Pengertian humor memang mempunyai pengertian bermacam-macam namun kesemuanya memiliki maksud yang sama. Humor merupakan suatu kegiatan yang identik dengan kelucuan yang dapat dituturkan oleh penutur untuk merangsang seorang atau penerima tutur untuk tertawa. Stand up comedy merupakan salah satu bentuk humor yang dilakukan oleh seorang diri dengan tujuan untuk menghibur dengan menghadirkan lawakan melalui lisan dan gerak tubuh. 


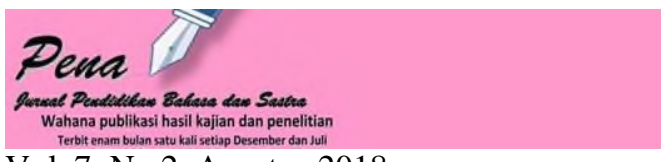

Vol. 7, No.2, Agustus 2018,

P-ISSN: 2089-3973, E-ISSN: 2615-7705

DOI: https://doi.org/10.22437/pena.v7i2.5316

\section{Kritik Sosial}

Sebagaimana dijelaskan sebelumnya menurut tujuannya, humor digunakan tidak hanya untuk menghibur, namun juga dapat digunakan untuk melakukan suatu kritik terhadap ketimpangan atau ketidak harmonisan terhadap suatu keadaan. Mahfud (1997:47) menyatakan bahwa kritik sosial merupakan suatu aktivitas yang mempunyai hubungan dengan penilaian, perbandingan, serta pengungkapan tentang kondisi sosial dalam suatu masyarakat yang terkait dengan nilai yang dianut serta nilai yang dijadikan sebagai dasar. Dikaitkan dengan humor, kritik sosial merupakan wahana untuk mengungkapkan ketimpangan yang terjadi di masyarakat. Melalui humor yang menjadi sarana yang efektif untuk mengungkapkan kritik disaat kritik lain tidak dapat menjalankan fungsinya. Wijana (2003:1) menyatakan bahwa melalui humor, individu dapat menghadapi persoalan sosial dengan tawa. Sementara untuk sasaran kritik yang diungkapkan tidak begitu dirasakan mempermalukan yang dikritik karena disampaikan dengan jenaka.

\section{Pragmatik}

Menurut Wijana (1996:2) pragmatik merupakan cabang ilmu linguistik yang menelaah makna satuan lingual secara eksternal dan memiliki makna sesuai konteks. Objek yang dikaji dalam pragmatik adalah maksud penutur. Pragmatik menurut Soeparno (2002: 27) merupakan subdisiplin linguistik yang mempelajari mengenai penerapan atau penggunaan bahasa dalam komunikasi sosial yang mempertimbangkan faktor situasi, maksud pembicaraan dan status lawan tutur. Dari berbagai pengertian menurut para ahli dapat disimpulkan bahwa pragmatik adalah cabang ilmu bahasa yang mempelajari mengenai penggunaan bahasa sebagai alat komunikasi antara penutur dan pendengar yang memperhatikan konteks.

Ruang lingkup yang terdapat dalam pragmatik menurut Yule (2006: 3-4); (1) Pragmatik merupakan studi mengenai maksud penutur. Dalam konteks ini, pragmatik merupakan studi tentang makna yang disampaikan oleh penutur dan ditafsirkan oleh pendengar. (2) Pragmatik meruakan studi mengenai makna kontekstual. Pada tipe ini, perlu melibatkan penafsiran mengenai apa yang dimaksudkan orang dalam suatu konteks khusus dan bagaimana konteks tersebut berpengaruh pada apa yang dikatakan. Diperlukan suatu pertimbangan mengenai bagaimana cara penutur mengatur apa yang ingin mereka katakan dan disesuaikan dengan 


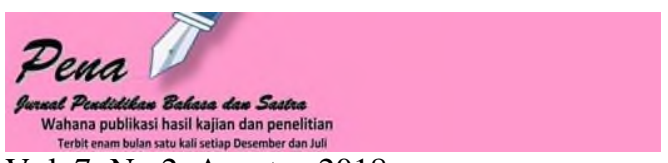

Vol. 7, No.2, Agustus 2018,

P-ISSN: 2089-3973, E-ISSN: 2615-7705

DOI: https://doi.org/10.22437/pena.v7i2.5316

orang yang mereka ajak bicara, dimana, kapan dan dalam keadaan apa. (3) Pragmatik merupakan studi mengenai bagaimana agar yang disampaikan lebih banyak dari pada dituturkan. Pendekatan menyelidiki mengenai bagaimana cara pendengar dapat menyimpulkan. Mengenai apa yang ditururkan agar dapat sampai pada inteprestasi makna yang dimaksudkan penutur. Studi yang ketiga ini merupakan studi pencarian makna. (4) Pragmatik merupakan studi mengenai ungkapan dari jarak hubungan. Pandangan ini menimbulkan pertanyaan mengenai apa yang menentukan pilihan antara yang dituturkan dan tidak dituturkan.

Aspek-aspek yang harus ada dalam rangka studi pragmatik menurut Leech (1993: 11).

1. Penutur dan Lawan Tutur

Konsep penutur dan lawan tutur mencakup penulis dan pembaca jika tuturan dikomunikasikan dengan tulisan, aspek yang berkaitan dengan penutur dan lawan tutur adalah usia, pendidikan, latar belakang sosial, ekonomi, jenis kelamin, tingkat keakraban dan seterusnya.

2. Konteks Tuturan

Konteks tuturan dalam linguistik mencangkup segala aspek fisik (cotext) atau setting sosial (konteks) yang relevan dari tuturan bersangkutan. Konteks pada pragmatik pada hakikatnya merupakan semua latar pengetahuan yang dipahami bersama oleh penutur dan lawan tutur.

3. Tujuan Tuturan

Bentuk tuturan yang diungkapkan oleh penutur dilatarbelakaangi oleh maksud dan tujuan tertentu. Bentuk tuturan yang bermacam-macam, dapat digunakan untuk menyatakan maksud yang sama atau sebaliknya. Di dalam pragmatik, berbicara merupakan aktivtitas yang berorientasi pada tujuan. Misalnya: pagi, selamat pagi, met pagi dapat digunakan untuk menyatakan maksud yang sama, yaitu menyapa. Selain itu, selamat pagi dengan berbagai variasinya bila diucapkan dengan nada tertentu, dan situasi tertentu dapat pula digunakan untuk mengejak teman yang terlambat datang pada suatu acara. Jadi, ada perbedaan dasar antara pandangan pragmatik yang bersifat fungsional dengan pandangan gramatikal yang bersifat formal. Kriteria ketiga yaitu kalimat anomali. Misalnya Cristian Ronaldo 


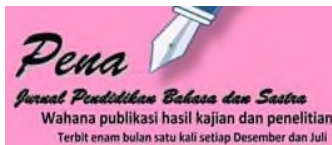

Vol. 7, No.2, Agustus 2018,

P-ISSN: 2089-3973, E-ISSN: 2615-7705

DOI: https://doi.org/10.22437/pena.v7i2.5316

dipermainkan bola, maksud dari kalimat ini adalah mengungkapkan bahwa Cristian Ronaldo tidak pintar bermain bola.

4. Tuturan Sebagai Bentuk Tindakan

Pada hubungan ini, pragmatik menangani bahasa sebagi tingkatan yang lebih kongkret dibanding dengan tata bahasa. Tuturan sebagai entitas yang kongkret jelas penutur dan lawan tuturnya, waktu dan tempat pengaturanya.

5. Tuturan Sebagai Produk Tindak Verbal

Tuturan yang digunakan dalam pragmatik seperti pada kriteria keempat adalah bentuk tindak tutur. Oleh karena itu, tuturan yang dihasilkan merupakan bentuk tindakan verbal. Contoh: Apakah penampilanmu tidak berlebihan? Kalimat ini dapat ditafsirkan sebagai pertanyaan dan perintah.

\section{Tindak Tutur dan Prinsip Kerja Sama}

Tindak tutur merupakan satu konsep pragmatik yang menghasilkan tindak sosial dimana sebuah tuturan sealin berfungsi untuk mengatakan atau menginformasikan sesuatu, dapat juga dipergunakan untuk melakukan sesuatu (Sari, 2014:39). Senada dengan hal tersebut Yule (2006: 82) mengungkapkan bahwa tindak tutur merupakan suatu tindakan yang ditampilkan melalui ujaran dalam proses komunikasi. Tindak tutur memusatkan perhatian pada cara penggunaan bahasa dalam mengkomunikasikan maksud dan tujuan penutur. Jadi, dapat disimpulkan bahwa tindak tutur merupakan suatu tindakan yang dilakukan melalui ujaran dalam suatu proses komunikasi yang dipengaruhi oleh konteks berbicara.

Pada proses komunikasi yang sering terjadi agaknya dapat diasumsikan bahwa seorang penutur mengartikulasikan ujaran dengan maksud untuk mengkomunikasikan sesuatu kepada lawan tutur serta berharap lawan tutur dapat memahami mengenai apa yang sedang dikomunikasikan. Untuk itu, penutur akan berusaha agar tuturanya selalu jelas, mudah dipahami, relevan dengan konteks. Suatu wacana dapat terbentuk jika terdapat kepatuan terhadap prinsip-prinsip komunikasi. Salah satu prinsip komunikasi adalah prinsip kerja sama. Adapun prinsip kerja sama menurut Grice, Parker, Wardaugh, Sperber dan Wilson (1986: 33-34) terbagi dalam empat maksim; (1) maksim kuantitas, (2) maksim kualitas, (3) maksim relevansi, (4) maksim pelaksanaan. 


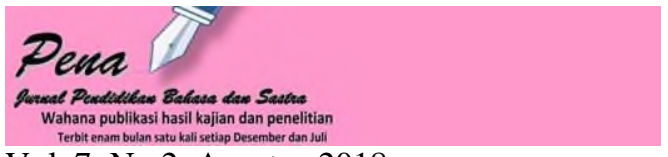

Vol. 7, No.2, Agustus 2018,

P-ISSN: 2089-3973, E-ISSN: 2615-7705

DOI: https://doi.org/10.22437/pena.v7i2.5316

a. Maksim kuantitas

Maksim kuantitas merupakan maksim yang menghendaki peserta pertuturanya memberikan kontribusi yang cukup atau sebanyak yang dibutuhkan oleh lawan bicara.

b. Maksim Kualitas

Maksim kualitas merupakan maksim yang mewajibkan setiap peserta percakapan mengatakan hal yang sebenarnya. Kontribusi peserta percakapan hendaknya didasarkan pada bukti yang memadai.

c. Maksim Relevansi

Maksim relevansi merupakan maksim yang mengharuskan sertiap peserta percakapan memberikan kontribusi yang relevan dengan masalah pembicaraan.

d. Maksim Pelaksanaan

Makism pelaksanaan merupakan maksim yang mengharuskan setiap peserta percakapan secara langsung, jelas, tidak kabur. Melalui maksim pelaksanaan, seorang penutur diharuskan menafsirkan kata-kata yang digunakan oleh lawan bicara secara taksa berdasarkan konteks pemakainya. Hal ini didasari pada prinsip bahwa ketaksaan tidak akan muncul jika kerja sama antara peserta tindak tutur selalu dilandasi oleh aspek-aspek yang dijelaskan oleh Lech pada pernyataan sebelumnya.

\section{PEMBAHASAN}

Wujud Penyimpangan Prinsip Kerja Sama yang Terdapat dalam Stand Up Comedy Indonesia Season 4 Show 9-Ronde 1 Oleh Comic Abdurrahum Arsyad

Pada bagian ini dijelaskan mengenai analsisis wujud penyimpangan prinsip kerjasama dalam stand up comedy yang disampaikan oleh comic Abdur Arsyad dalam acara stand up comedy Indonesia Season 4 Show 9-Ronde 1.

\section{Penyimpangan Maksim Kuantitas}

Maksim kuantitas merupakan maksim yang menghendaki peserta pertuturannya memberikan kontribusi atau informasi yang cukup atau sebanyak yang dibutuhkan oleh lawan bicara. Kontribusi atau informasi ini tidak boleh melebihi informasi yang sebenarnya dibutuhkan si penutur. Tindak tutur yang tidak mengandung informasi yang diperlukan mitra tutur, maka dikatakan melanggar maksim kuantitas. Pada stand up comedy yang disampaikan 


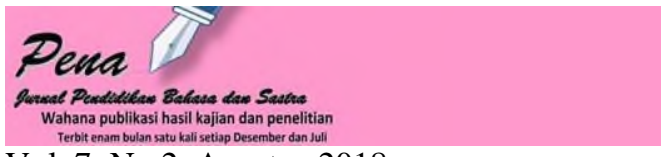

Vol. 7, No.2, Agustus 2018,

P-ISSN: 2089-3973, E-ISSN: 2615-7705

DOI: https://doi.org/10.22437/pena.v7i2.5316

oleh comic Abdur Arsyad dalam acara stand up comedy Indonesia season 4 show 9-ronde 1, ditemukan penyimpangan terhadap maksim kuantitas. Berikut contoh pembahasan wujud penyimpangan maksim kuantitas.

"Ketika Jakarta itu punya Persija Jakarta, Malang punya Arema Malang, Kupang itu juga punya namanya Persatuan Sepakbola Kupang disingkat PSK Kupang”.

Tuturan di atas, melanggar maksim kuantitas dikarenakan tuturan yang berlebih dan tidak sesuai dengan kebutuhan. Penutur memberikan tuturannya secara berlebihan dengan menambahkan hal-hal yang seharusnya tidak dituturkan. Sebenarnya dengan menyebut nama tim sepak tanpa harus disingkat sudah dapat menjelaskan mengenai nama tim yang berasal dari Kupang.

\section{Penyimpangan Maksim Kualitas}

Maksim kualitas merupakan maksim yang mewajibkan setiap peserta percakapan mengatakan hal yang sebenarnya. Kebenaran tersebut harus didukung dengan bukti yang jelas. Tutur yang tidak didukung dengan bukti yang jelas maka dapat dikatakan melanggar maksim kualitas. Pada stand up comedy yang disampaikan oleh comic Abdur Arsyad dalam acara stand up comedy Indonesia season 4 show 9-ronde 1, ditemukan penyimpangan terhadap maksim kuantitas. Berikut contoh pembahasan wujud penyimpangan maksim kualitas.

"Dikampung saya itu kalau kita bermain bola itu tidak pernah berpatokan pada $2 \times 45$ menit. Sepak bola berakhir ketika sudah terjadi baku pukul”.

Tuturan di atas menjelaskan mengenai permainan sepak bola yang dimainkan di kampung penutur tidak menggunakan batas waktu ketika mengakhiri permainan namun permainan sepak bola berhenti ketika terjadi baku pukul. Tuturan tersebut melanggar maksim kualitas dikarenakan penutur berbohong dalam memberikan informasi.

\section{Penyimpangan Maksim Relevansi}

Maksim relevansi adalah maksim yang mengharuskan setiap peserta tindak tutur memberikan kontribusi yang relevan dengan masalah pembicaraan. Bertutur dengan tidak memberikan kontribusi dianggap melanggar prinsip relevansi. Pada stand up comedy yang disampaikan oleh comicAbdur Arsyad dalam acara stand up comedy Indonesia season 4 show 


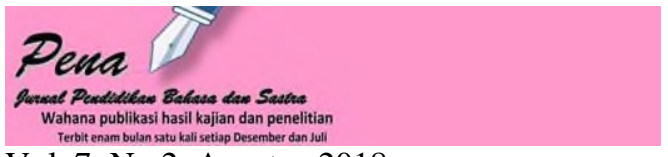

Vol. 7, No.2, Agustus 2018,

P-ISSN: 2089-3973, E-ISSN: 2615-7705

DOI: https://doi.org/10.22437/pena.v7i2.5316

9-ronde 1, ditemukan penyimpangan terhadap maksim relevansi. Berikut contoh pembahasan wujud penyimpangan maksim relevansi.

"Di Malang itu saya suka menonton Arema di stadion dan aremania itu disana itu sudah ada kubu-bunya ada arema tribun utara, tribun selatan, tribun ekonomi, manajemen, akutansi macam-macam”.

Pada tuturan di atas menginformasikan bahwa suporter Arema yang disebut dengan Aremania sudah terbagi menjadi kubu-kubu sesuai dengan tempat duduk yang sering mereka tempati ada di stadion. Pada tuturan "Di Malang itu saya suka menonton Arema di stadion dan aremania itu disana itu sudah ada kubu-bunya ada arema tribun utara, tribun selatan, tribun ekonomi manajemen akutansi macam-macam”. Melanggar maksim relevansi dikarenakan tuturan tersebut melanggar dari topik yang ditentukan. Pelanggaran tuturan yang dituturkan terletak pada kalimat "arema tribun utara, tribun selatan, tribun ekonomi, manajemen, akutansi macam-macam”. Tuturan ini menyimpang karena tidak ada tribun ekonomi, manajemen, akutansi tidak ada hubungan sama sekali dengan pembicaraan awal mengenai kubu pada suporter Aremania.

\section{Penyimpangan Maksim Pelaksanaan}

Maksim pelaksanaan merupakan maksim yang mengharuskan setiap peserta percakapan secara langsung, jelas, tidak kabur. Pada stand up comedy yang disampaikan oleh comic Abdur Arsyad dalam acara stand up comedy Indonesia season 4 show 9-ronde 1, ditemukan penyimpangan terhadap maksim pelaksanaan. Berikut contoh pembahasan wujud penyimpangan maksim pelaksanaan.

"Paling tidak enak kalau kalian itu nonton dari tribun timur karena di tribun barat itu nonton pake lampu dengan cahaya terang kelap kelip dimana-mana tapi ditribun timur itu masih gelap listrik tidak ada ".

Pada tuturan diatas dapat dikatakan melanggar maksim pelaksanaan dikarenakan penutur memberikan informasi yang dapat bermakna ganda. Bermakna ganda disini berkatian denga kata tribun barat dan tribun timur. Tribun barat dan timur disini bisa dikatakan tribun dengan arti sebenarnya adalah tempat duduk penonton dan tribun barat dan tribun timur disini dapat diartikan sebagai wilayah. 


\section{Perspektif Pragmatik : Kritik Sosial yang Terdapat pada Stand Up Comedy yang Disampaikan Oleh Abdur Arsyad}

Kritik sosial dianggap sebagai sarana komunikasi yang mempunyai fungsi sebagai alat kontrol terhadap jalannya sistem sosial yang berlaku di masyarkat. Humor merupakan sarana kritik sosial terhadap penyimpangan yang terjadi dalam masyarakat. (Mahfud, 1997:47) menyatakan bahwa kritik sosial merupakan suatu aktivitas yang mempunyai hubungan dengan penilaian, perbandingan, serta pengungkapan tentang kondisi sosial dalam suatu masyarakat yang terkait dengan nilai yang dianut serta nilai yang dijadikan sebagai dasar. Pada pembahasan ini membahas mengenai analisis kritik sosial yang terdapat dalam stand up comedy yang disampaikan oleh comic Abdur dalam acara stand up comedy Indonesia season 4 show 9-ronde 1 dan maksim yangg dilanggar untuk mendapatkan efek lucu dalam menyampaikan tuturan.

\section{Kritik Sosial Penilaian}

Kritik sosial penilaian mengacu pada penilaian penutur kepada seseorang atau kelompok orang dalam melaksanakan peran dalam masyarakat. Penilaian ini dapat mencangkup penilaian negatif ataupun positif. Kritik sosial yang menimbulkan efek lucu dalam stand up comedy ditimbulkan karena penutur melakukan penyimpangan terhadap maksim kuantitas atau kualitas. Hal ini dapat diartikan dalam menyampaikan kritik sosial, penutur cenderung memberikan pernyataan yang tidak sebenarnya dan memberikan informasi dengan porsi berlebih. Berikut penyimpangan-penyimpangan yang ditemukan berkaitan dengan kritik sosial akibat penyimpangan terhadap maksim kuantitas dan kualitas yang menimbulkan efek lucu dalam stand up comedy yang disampaikan oleh Abdur dalam acara stand up comedy Indonesia season 4 show 9-ronde 1.

"Tapi teman-teman anak timur kebanyakan itu rata-rata hebat main bola kalau ada tidak hebat main bola paling tidak dia hebat berbicara bola. Anak timur kalau ngomong bola udah macam kerusuhan"Aduh mama sayange, kemarin kita bermain bola kenapa itu tidak disiplin jaga pos, pertahanan hancur, serangan tidak kuat, bunuh diri sampai lima".

Pernyataan yang mengandung humor tersebut menunjukan penilaian penutur bahwa orang diwilayah timur banyak yang pandai bermain bola dan memiliki semangat yang tinggi. Untuk mendukung pernyataannya, penutur memberikan contoh percakapan yang dilakukan 


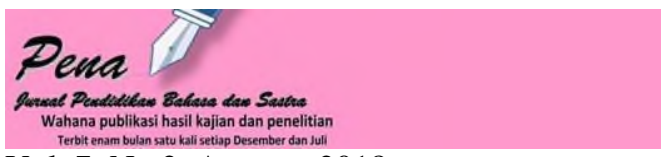

Vol. 7, No.2, Agustus 2018,

P-ISSN: 2089-3973, E-ISSN: 2615-7705

DOI: https://doi.org/10.22437/pena.v7i2.5316

oleh seseorang yang sedang membicarakan masalah sepak bola. Namun pernyataan di atas melanggar maksim kuantitas karena penutur memberikan tuturanya secara berlebihan contohnya pernyataan "udah macam kerusuhan”.

\section{Kritik Sosial Perbandingan}

Kritik sosial perbandingan merupakan pembandingan suatu kondisi sosial satu dengan lain. Berikut analisis kritik sosial perbandingan yang menimbulkan efek lucu.

"Ditribun barat itu di kasih kursi di kasih sofa makan enak-enak tapi di tribun timur masih beralaskan tanah makan seadanya".

Pernyataan di atas merupakan kritikan terhadap kondisi sosial yang ada di NTT, penutur membandingkan antara keadaan ekonomi dan fasilitas yang ada dikawasan timur dengan barat yang sangat timpang. Cara penutur menjelaskan mengenai kesenjangan yang ada di wilayah barat dan timur ini begitu runtut. Akan tetapi penutur melakukan pelanggaran pada maksim pelaksanaan dengan membuat istilah tribun barat dan timur. Tribun disini dapat memiliki dua makna tribun dengan arti sebenarnya adalah tempat duduk penonton dan tribun disini dapat diartikan sebagai wilayah.

\section{Kritik Sosial Pengungkapan}

Kritik sosial pengungkapan merupakan kritik yang mengungkapkan kondisi sosial yang terjadi ketika penutur melakukan tuturan. Kritik sosial pengungkapan ini diungkapkan penutur dengan melanggar maksim kuantitas, kualitas, relevansi, dan cara dalam menghasilkan kelucuan yang membungkus kritik sosial.

\section{"Akhirnya saya berpikir kayaknya saya harus buat kubu sendiri Aremania tribun tenggara timur laut. Yang lain bawa terompet kami bawa kompas".}

Tuturan di atas menunjukan kritik penutur terhadap kemunculan berbagai kubu dalam suporter Aremania. Dikarenakan banyaknya kubu dalam suporter Aremania penutur berinisiatif untuk membuat kubu suporter sendiri yaitu Aremania tribun tenggara timur laut. Saat mengungkapkan kondisi tersebut, pengaruh lucu dihasilkan penutur dengan melanggar makim relevansi yaitu mengubah topik yang tidak relevan dengan apa yang biasanya dibawa oleh suporter yaitu mengenai suporter yang selalu membawa trompet dan kubu yang dibuat penutur membawa kompas. 


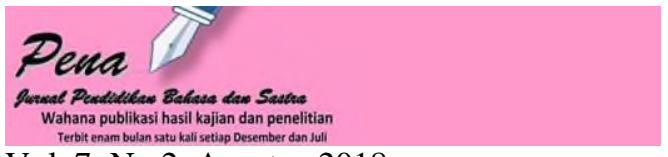

Vol. 7, No.2, Agustus 2018,

P-ISSN: 2089-3973, E-ISSN: 2615-7705

DOI: https://doi.org/10.22437/pena.v7i2.5316

\section{SIMPULAN}

Bedasarkan hasil analisis dan pembahasan yang sudah diuraikan sebelumnya, dapat disimpulkan bahwa wujud penyimpangan prinsip kerja sama yang terdapat dalam stand up comedy Indonesia season 4 show9-ronde 1 oleh comic Abdurrahum Arsyad terdiri dari penyimpangan maksim kuantitas, maksim kualitas, maksim relevansi dan maksim pelaksanaan. Selanjutnya, stand up comedy merupakan salah satu jenis humor yang berkembang di masyarakat yang diungkapkan dengan melanggar maksim kuantitas, kualitas, relevansi, dan pelaksanaan. Stand up comedy dapat digunakan sebagai sarana untuk menyampaikan kritik sosial karena dapat diungkapkan dengan bahasa yang harmonis dan mempunyai kesan santai serta menggelitik.

\section{DAFTAR PUSTAKA}

Berger, Arthur Asa. 2012. An Anatomy of Humor. United States of America : Transaction Publishers.

Chaer, Abdul. 2010. Kesantunan Berbahasa. Jakarta: Rineka Cipta.

Firmansyah, M.B \& Rokhmawan, T. 2016. "Representasi Bahasa Humor dalam Acara Stand Up Comedy Di Metro TV”. Kembara. Volume 1, Nomor 1, 41-47.

Leech, Geoffrey. 1993. Prinsip-prinsip Pragmatik. Jakarta : Penerbit Universitas. Indonesia (UI-Press).

Parker, Frank. 1986. Linguistics for Non-Linguists. London: Taylor and Farncis, Ltd.

Levinson, Stephen C. 1983. Pragmatics. Cambridge: Cambridge University Press.

Mahfud, M.D. 1997. Kritik Sosial dalam Wacana Pembangunan. Yogyakarta: UII Press.

Papana, Ramon. 2012. Kiat Tahap Awal Belajar Stand Up Comedy Indonesia: Kitab Suci. Jakarta: PT Trans Media.

Pradopo, Rachmat Djoko. 1987. Pengkajian Puisi : Analisis StrataNorma Dan Analisis Struktural dan Semiotik, Yogyakarta : Gadjah Mada University Press.

Purba, A. 2011. Tindak Tutur dan Peristiwa Tutur. Pena. Volume 1, Nomor 1, 77-91.

Rahmanadji, D. 2007. Sejarah, Teori, Jenis, dan Fungsi Humor. Volume 35, Nomor 2, 213221. Diambil dari http://sastra.um.ac.id/wp-content/uploads/2009/10/Sejarah-TeoriJenis-dan-Fungsi-Humor.pdf. 


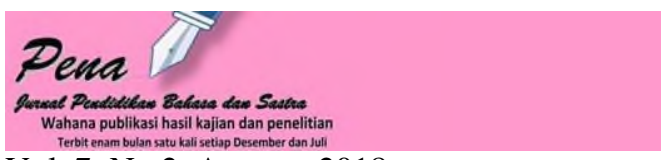

Vol. 7, No.2, Agustus 2018,

P-ISSN: 2089-3973, E-ISSN: 2615-7705

DOI: https://doi.org/10.22437/pena.v7i2.5316

Ristiawan, H. 2017. Prinsip Kerja Sama dalam Berinteraksi Di Lingkungan SMP N 11 Kota Jambi. Pena. Volume 7, Nomor 2, 99-116.

Sari, I. R. 2014. Analisis Pragmatik Pelanggaran Tindak Tutur Guru Di SMA Lentera. Pena. Volume 4, Nomor 1, 37-50.

Saputra, S, Wiryotinoyo, M, Akhyarudin, A. 2015. Implikatur Percakapan dalam Stand Up Comedy Indonesia Di Stasiun Kompas TV Edisi April 2014. Jurnal Pena. Volume 5, Nomor 1, 86-99.

Setiawan, Arwah. 1990. Teori Humor. Jakarta: Majalah Astaga, No. 3 Th. III.

Soeparno. 2002. Dasar-dasar Linguistik. Yogya: PT Tiara Wacana Yogya.

Wijana, I Dewa Putu.1996. Dasar-Dasar Pragmatik . Yogyakarta: Andi Offset. 2003. Wacana Dagadu, Permainan Bahasa, Ilmu Bahasa. Pidato Pengukuhan Guru Besar. Yogyakarta: UGM.

. 2004. Kartun: Studi tentang Permainan Bahasa. Yogyakarta: Ombak. Yule, George. 2006. Pragmatik. Yogyakarta : Pustaka Pelajar. 